\title{
Women Living in Solitude: A Case Study of The Base of an Old Girl and Hitorigurashi Mo 5 Nen Me
}

\author{
Kin-Wai Chu ${ }^{1 *}$
}

Published: April 11, 2020

\begin{abstract}
Autobiographical graphic novels have become a salient cultural production and a popular art form for feminists to express themselves nowadays. The graphic life stories privileged by feminist comic scholarship are often related to sexuality, trauma and unspeakable taboos while other themes are less explored. This article is a case study focusing on the visual and narrative analysis of two alternative feminist comic diaries: The Base of an Old Girl (2009), created by the Hong Kong artist Stella So; and Hitorigurashi Mo 5 Nen Me (2003) (literally translated as living alone for the fifth year), created by the Japanese artist Naoko Takagi. These works are composed of episodic everyday stories and the overarching narratives embody a sense of joy of living in solitude. Drawing on the manga aesthetic of 'kawaii' (cuteness), So and Takagi depict infantilised visual imagery and discursive practices in their comic diaries. This suggests a transcultural configuration of femininity that departs from the conventional emphasis on the female body and sexuality in feminist studies.
\end{abstract}

Keywords: Feminist comics, comic diaries, singleness, kawaii, solitary living

\section{INTRODUCTION}

Feminism not only aims at achieving gender equality but also repositioning women as subjects by highlighting women's agency. Stressing the subjectivity of femininity helps recognise its multiplicity so as to diversify current social constructionist points of view (e.g. Berger, 1972; Betterton, 1987; Jones, 2010; Klein, 1993). Likewise, to understand the construction of femininity in Asia, one cannot rely solely on the existing knowledge of western feminism. This article will look into a changing phenomenon of East Asian single women who embrace their singleness. It will do so through a case study of two autobiographical comic diaries: Stella So's The Base of an Old Girl (2009) and Naoko Takagi's Hitorigurashi Mo 5 Nen Me (2003). The first part of this article contextualises feminism and comics from a historical and transnational perspective. The second part discusses the visual features of the two diaries in relation to the western culture of cuteness and the Japanese culture of kawaii. The third part analyses the solitary life narratives in the diaries that reflect an emerging positive notion of singleness amongst East Asian societies. Lastly, the article will propose that the comic characters of So and Takagi can be understood to represent a strand of girl-child femininity that manifests the cross-pollinations of the feminist trends of cuteness and kawaii as well as the postmodernist kidult phenomenon (Ngai, 2012).

\section{FEMINISM AND COMICS}

Comics as a mass medium can be traced back to the British caricature or cartoon in humour periodicals published in the eighteenth century. These early comics were mainly produced and read by men. By the turn of the nineteenth century, women started to play a more active role in the production of political cartoons, leading to the emergence of early comics by and for women in different countries. In Anglophone contexts, the development of comics has gone hand in hand with the feminist movements, for example in the first feminist wave, which was epitomised by universal suffrage activism, many suffragists took cartoons as a means to promote their campaign. One example is the poster made by Emily J. Harding Andrews with the title 'Convicts and Lunatics' (1907-1922),

${ }^{1}$ Doctoral student at the Katholieke Universiteit Leuven and PhD Fellow of The Researcher Foundation of Flanders (FWO), BELGIUM

*Corresponding Author: Kinwai.chu@kuleuven.be 


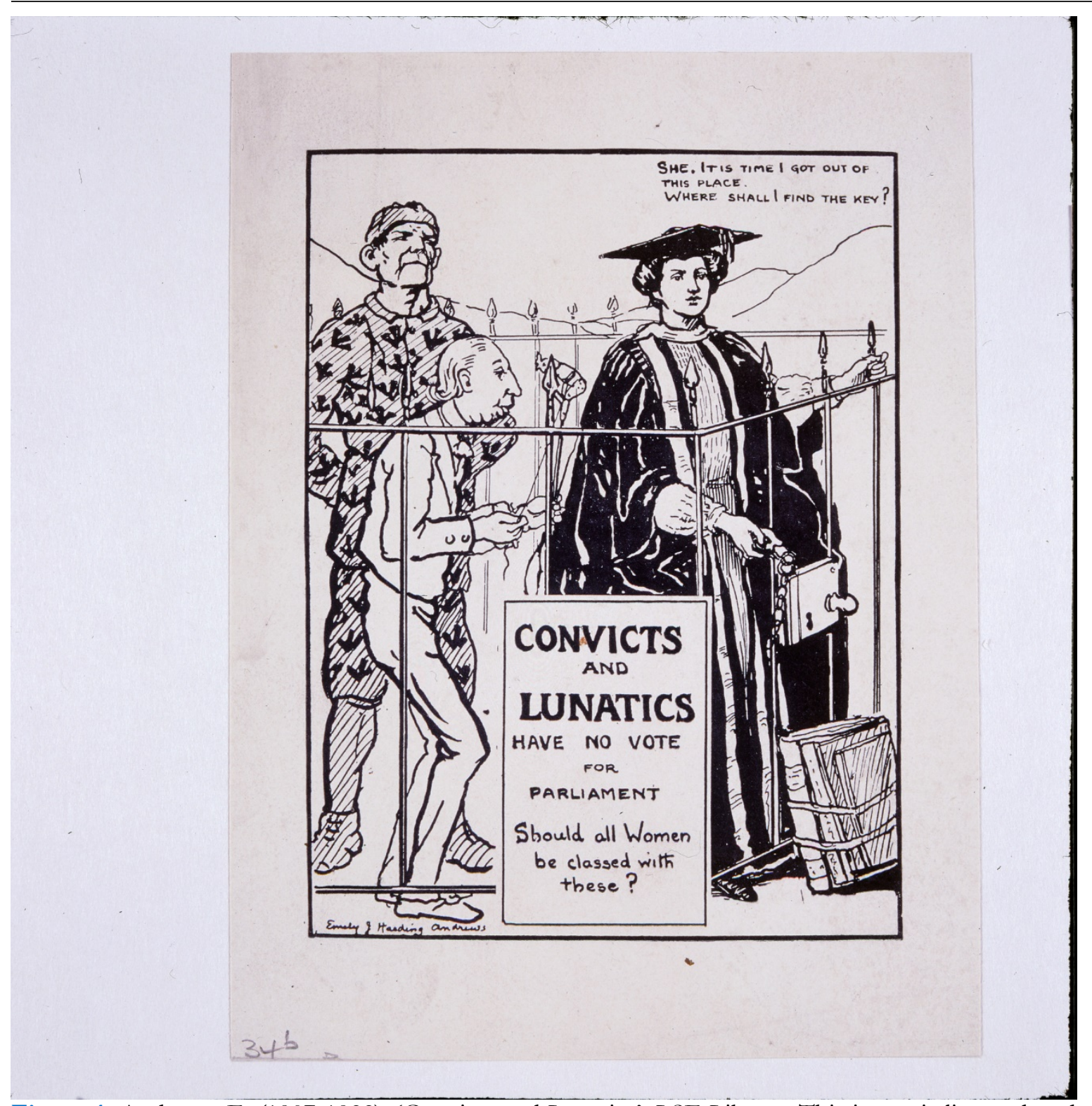

Figure 1. Andrews, E. (1907-1922). 'Convicts and Lunatics', LSE Library. This image is licensed under CC BYNC-SA3.0. ${ }^{1}$

which showed an intellectual woman who is symbolised by her academic cap and gown being locked up with a convict and a man with mental health issues (Figure 1).

The second wave of feminism coincided with the Anglophone underground comix movements from the 1960s to 1970s, and they demonstrated a profound synergy (Chute, 2010; Robbins, 1999) ${ }^{2}$. Trina Robbins, a renowned women comics historian, comics artist, and cofounder of the first all-women comic book in 1970, claimed that the underground comix scene was male-dominated in the 1960s until feminist artists gradually gathered momentum during the 1970s (Robbins, 1999: 85). Underground comix were a cottage industry, mostly self-published at a low cost, so liberated feminists whose voices were silenced in mainstream media could surpass institutional mediation in the comix creation process. As a result, feminist comix not only empowered women artists by disrupting the imbalanced power relations between publishers and author-artists, they also offered representations of empowerment. In the early 1990s, the third wave of feminism shifted towards individualism and diversity, and this came in tandem with the rise of alternative comics movement (Streeten and Tate, 2017; Walker, 2006). Alternative

\footnotetext{
${ }^{1}$ Photographic postcard 'Convicts and Lunatics' by Emily J. Harding Andrews from Mary Lowndes Album (1907-1922), ID 234135.3, Women's Library Suffrage Banners Collection, The Women's Library, LSE Library. The digital version is available at The Visual Arts Data Service (VADS), (https://vads.ac.uk/large.php?uid=78643\&sos=5). This image is licensed under Creative Commons Attribution-NonCommercial-ShareAlike (CC BY-NC-SA 3.0) (https://creativecommons.org/licenses/ by-nc-sa/3.0/).

${ }^{2}$ Underground 'comix' movement took place in the USA where a group of comics artists explored x-rated topics (for details, see further Sabin, 1996).
} 
comic author-artists differentiate their works from mainstream comics mainly by sole authorship and specific aesthetic pursuits or trends (Hatfield, 2005).

Roughly at the same time, the graphic novel emerged as a subcategory of alternative comics but with an emphasis on narrativity and literariness. The graphic novel elevated the status of comics by following the publication format and distribution channels of literary books and it represents a 'significant aspect of comics and literary history' (Baetens, Frey and Tabachnick, 2008:1). Female artists are more visible in this graphic novel scene in which some canonised works, by Alison Bechdel, Phoebe Gloeckner, and Marjane Satrapi to name but a few, have not only attracted widespread scholarly attention but also arguably made autobiographical feminist comics become 'today's most riveting feminist cultural productions' (Chute, 2010: 2). Although most comics theories and the comics corpus chosen for academic studies have been established in the European and North American contexts, the recent decade has seen burgeoning research that enriches the spectrum of comics from transnational, multicultural, and wider global perspectives (Aldama, 2010; Brienza, 2015; Denson, et al., 2013; Heimermann and Tullis, 2017; Lent, 2015).

\section{FEMINISM AND COMICS IN EAST ASIAN CONTEXTS}

Lisa Bloom claims that western feminist movements have not been directly adopted in Asian societies partly because of the relatively 'strong patriarchal familial contexts in Asia, making Asian women still more bound by traditional notion of womanhood (2010: 16)'. Manga constitute an indispensable component of Japanese popular culture, so manga for women can be taken as a departure point for the cultural study of Japanese feminism. The highly stratified manga market reaches all walks of life because manga are not just classified according to genre but also according to the gender and age group of the target audience (Ito, 2005; Schodt, 1986). Shöjo manga, for instance, is manga for teenage girls, while Josei (or radikomi and rediisu) manga targets adult women. In the early 1970s, a group of female manga artists (called the Year 24 Group or Nijtüyo-nen Gumi) revolutionised shöjo manga and their success also elevated the status of female manga artists (Shiokawa, 1999: 100).

Hong Kong comics have a strong affinity with manga. In the 1960s, Hong Kong became 'the earliest outlet of the global flow of manga from Japan' though most of the translated manga were pirated back then (Wong, 2006: 29). This gradually led to the 'Japanese [manga] boom' in Hong Kong since the 1980s (Lai and Wong, 2003: 116). Regarding the gender ratio and cultural production of comics, there have been significantly fewer female comic artists in Hong Kong. The most well-known female artists include Wai-chung Lee (who started her career in the 1960s and is coined as 'the mother' of Hong Kong girl's comics), Alice Mak, Rainbow Leung and Little Thunder.

Japan and Hong Kong are not simply tied to each other in terms of commerce, but also in terms of their cultural proximity (Bridges, 2005; Roger, 1989). Both of their traditional social values are shaped by Confucianism to various degrees. Both have also experienced more drastic westernisation, largely caused by trade, religious activities and political processes ${ }^{3}$. Japanese ports were forced to open up to international trade in the 1850s, followed by the explicit national goal to modernise or westernise the country during the Meiji period (1868-1912) and the Taishō period (1912-1926). Similarly, British colonisation (1842-1997) transformed Hong Kong into a cosmopolitan city, idiomatically blending East and West.

The hybridised sociocultural constructions of Japan and Hong Kong highlight the fluidity and heterogeneity of Asian cultures, which cannot be labelled as or reduced to a 'homogeneous totalizing whole' (Darling-Wolf, 2015:8). Likewise, the term 'Asian feminist comics' is a homogeneous category that undermines the diversity of such comics. Therefore, this article presents two indicative case studies by analyzing one Japanese and one Hong Kong comic diary in order to explore how such works can evince heterogeneous feminist sensibilities that can broaden and reflect upon the complexity of existing feminist discourse. This choice of corpus takes into account the fact that diaries are a key genre in feminist studies, since autobiographical writing and everyday life experiences can foreground socially and personally constructed gender identities (Gibson, 2015; Hirschman, 2003; McRobbie, 2004). Everyday life narratives have also been an increasingly popular theme in the contemporary and global comics' scene over the past few decades (Schneider, 2010).

\section{HITORIGURASHI MO 5 NEN ME AND THE BASE OF AN OLD GIRL}

The two comic diaries to be analysed in this article are the Japanese artist Naoko Takagi's Hitorigurashi Mo 5 Nen Me (2003), which literally means 'Living Alone for the Fifth Year'; and the Hong Kong artist Stella So's 老少

\footnotetext{
${ }^{3}$ Foreign contacts with Japan began in the fourteenth century but a closed-country policy was implemented during the Edo period (1603-1868), from the 1630s to the 1850s. Onna Daigaku (translated as 'the great learning for women') was written during the mid-Edo period to teach Japanese women Confucian values, including women's total submission to their husbands. 
女基地 (The Base of an Old Gir) (2009)4. Both Takagi and So depict themselves as cute and prepubescent girls. Their diaries also document solitary living in a positive way.

Takagi narrates the fifth year of living alone after moving to Tokyo in Hitorigurashi Mo 5 Nen Me (Hitorigurashi hereafter). Her diary is divided into sixteen chapters and each chapter discusses one issue about everyday solitary living, such as cooking simple dishes, watching horror movies, and rearranging furniture. When Takagi created this comic, she had already made her name with her debut autobiographical comic book, $150 \mathrm{~cm}$ Life (2003).

In The Base of an Old Girl, So depicts her new lease of life after moving out of her parents' home into her newly purchased apartment. The Base of an Old Girl (The Base hereafter) is a compilation of her eponymous weekly comic column in a Chinese-language newspaper called Mingpao. The Chinese title is literally translated as 'the base of an old teenage girl' which is a parody of the Japanese shojo manga series Pretty Guardian Sailor Moon (1991-1997) that is literally translated as 'Pretty teenage-girl warrior Sailor Moon' in Chinese. Thus, 'old teenage girls' is used satirically to describe mature women who still embrace the identity of teenage girls.

This article will provide a visual analysis of the female imagery and a thematic analysis of the discursive practices of singlehood and solitary living ${ }^{5}$. The selected works manifest direct influences from certain trends initiated in the West, namely, the feminist trends of singleness and girlhood, and the alternative comic trend of autobiography. On the surface, Takgai and So highlight girlhood instead of womanhood, following a recent tendency that obscures the boundary between girls and women (Handyside and Taylor-Jones, 2016). However, a closer examination from a transcultural perspective reveals that they have developed a specific form of femininity shaped by the East Asian and localised cultures.

\section{FEMINIST MOVEMENTS IN JAPAN AND HONG KONG}

Analysing the theme of solitary living presented with cute and kawaii aesthetics in So and Takagi's comic diaries requires a detour to situate the prevailing feminist theories in Japan and Hong Kong. Arguably, feminism began in the West, so when the western feminist movements reached Japan and Hong Kong, they intersected with the local culture in different fashions.

Western feminist ideas were introduced to Japan in the late nineteenth century. Throughout the 1920s, Japanese feminists challenged the highly patriarchal system and fought not only for voting rights but also for the right to divorce and to access higher education (Yoshihara, 2004). These demands were answered in the Post-war reforms in the late 1940s. Japanese feminists also followed the second wave of western feminism in the 1960s and 70s with some success. In terms of statistical evidence, Japan ranked 19th out of the 189 member states in both the Gender Development Index (GDI) and the Gender Inequality Index (GII), issued by the United Nations in $2017^{6}$. Nevertheless, even though the Gender Equality Employment Act came into effect in Japan in 1986, the traditional gender role of women as homemakers still holds strong. This is evident from the Global Economic Forum's Global Gender Gap Report (2018) which ranked Japan 110 th out of 148 countries. One indicator included in the report is the average number of hours spent on unpaid household chores by both men and women. The study indicated that Japanese women spend five times more time than men on housework. ${ }^{7}$ Therefore, it seems that Japan's topdown equality policies and initiatives have not yet truly aligned with the persistent socio-cultural realities of society.

In Hong Kong, the first feminist wave only emerged after the Second World War and continued until the 1970s, during which time women activists demanded egalitarian legal rights, such as abolishing polygamy and receiving

\footnotetext{
${ }^{4}$ The images of Hitorigurashi Mo 5 Nen Me used in this study is a Chinese translation published by Titan Publishing Co. Ltd in 2005 while the original Japanese version was published by Media Factory, Inc., a company of Kadokawa Future Publishing in 2003.

${ }^{5}$ In earlier research about single women, the word 'spinster' was used but it is embedded with negative and passive connotation so 'singleness' is used in this article following more recent studies that will be discussed in the later section (Macvarish, 2006: 5).

${ }^{6}$ The GDI measures life expectancy, knowledge and standard of living while GII measures health, empowerment and the labour market. Among the 189 member states included in the GDI, Hong Kong ranks 7th; Singapore ranks 9th; Japan 19th; the Republic of Korea 22th, China 86th (For the full report, http://hdr.undp.org/en/indicators/137906). The countries mentioned above obtained the same results in the GII, except for Hong Kong, which is not included in the GII for an unknown reason. As a part of China, Hong Kong is an associate member in the UN and this study takes the statistics of Hong Kong and China separately (For the full report, http://hdr.undp.org/en/indicators/68606).

${ }^{7}$ The Global Gender Gap Report takes into account the following indicators: economic participation and opportunity, educational attainment, health and survival, and political empowerment. In this study, Japan was ranked in position 117, 64, 41 and 125, respectively, leading to the overall ranking of 110. However, the ranking of Hong Kong is probably included in that of China, which obtained 103th place. Given the fact that the ranking of Hong Kong and China showed great disparity in the United Nations report as mentioned in Note 2, it seems to be more appropriate not to compare the situation in Hong Kong and Japan based on the results of this report. (http://www3.weforum.org/docs/WEF_GGGR_2018.pdf).
} 
'equal pay for equal work', while universal suffrage was not on the agenda due to Hong Kong's colonial status (Chiang and Liu, 2011: 557-8). When there were territory-wide elections for the two District Boards during the 1980s, both male and female adult citizens were eligible to register as voters. In terms of the Gender Development Index, Hong Kong was ranked highest in East Asia, occupying the $7^{\text {th }}$ place out of 189 member states worldwide. Highly inspired by western Marxist and socialist feminism, the second feminist wave in Hong Kong gave rise to different feminist research and activist groups in the 1980s (Chiang and Liu, 2011: 560-561). Unlike in Japan, the division of household labour is not an obvious indicator of gender inequality due to approximately 400,000 migrant domestic workers who are employed in Hong Kong households. The class and social problems associated with the employment of migrant domestic helpers are also informed by gender inequality, unfortunately though, this issue is beyond the scope of this current case study.

Since the 1990s, western feminist trends were diversified alongside decentralised structural and institutional spheres. Their cross-cultural impact on Hong Kong varies, for example, Shun-hing Chan (2009) notes that the recent feminist focus on everyday life in the West has sparked little interest in local academia in Hong Kong. Taking a critical postcolonial point of view, Sealing Cheng agrees with the postcolonial feminists' rejection of the idealisation of a 'global sisterhood' and calls instead for more attention to be paid to local sensitivities (2009: 21).

\section{THE VISUAL ANALYSIS OF GIRL-CHILD IMAGERY}

Sheri Klein (1993), who studies how femininity and sexuality are constructed in comics, claims that the imagery of women in mainstream comics, such as the superheroine comics, can be traced back to fine art traditions. In this context, the female body is usually highly sexualised and perfected to present the ideal body desired by men. In contrast to mainstream comics, most feminist comics are autobiographical and alternative comics, so they tend to display more individualistic and multifarious female imageries. Feminist comic artists are not only conscious of their self-portrayal and the central feminist issues such as the body and sexuality, but they are also aware of their defiant position to 'challenge stereotypical definitions of femininity' (Klein, 1993:63). Since comics stretch across a vast continuum that is inevitably bound by language, culture and various circumstantial factors, my analysis is limited by my own linguistic repertoire and exposure. As a result, the analysis is partial and only reflects a tiny facet of the myriad representations of Asian femininities. Even when solely focusing on feminist comic diaries, their diversity can still be daunting. So and Takagi's autobiographical diaries address different dimensions of feminism pertaining to single women as girls and singlehood while some of the key autobiographical trends in Anglophone feminist comics were saliently embedded with the 'identity politics' and trauma Johnson (2016) quoted in Kirtley, 2018: 277).

So and Takagi's characters (Figures 2 and 3) embody a girl-child imagery that is seen rarely in European and American feminist comics. Such portrayal reveals two cultural trends at work. The first is the postfeminist trend of 'girling the womanhood' propounded by Anita Harris, who identifies a paradigm shift in the definition of girls from a simple definition based on age to more complex definitions based on some additional parameters influenced by the 'twenties' phenomenon and the 'girlie movement' (2004: xx). This trend is inspired by the parallel and nongender specific postmodernist trend of kidulthood (Bernardini, 2014). The elastic construction of femininity means that 'the 'feeling' and 'doing' of a girl can attach to bodies of those other than young females' (Handyside and Taylor-Jones, 2016: 8). Angela McRobbie postulates that post-feminism signals the changing interest of feminist studies from the 'centralised power blocks' during the second wave to 'more dispersed sites, events and instances of power' since the 1990s (2004: 255-6). More importantly, she proposes that 'the tropes of freedom and choice' are 'inextricably connected with the category of young women' (2004: 255). In fact, the presence of girls in media is not a recent phenomenon at all, as six out of the ten top-grossing US movies of all time, such as Gone with the Wind (1939) and The Sound of Music (1965), feature a girl who is coming of age (Gateward and Pomerance, 2002: 14). However, until the recent decade, feminist studies of girls and girlhood were more overshadowed by topics such as sexuality and power relations.

This shifted notion of girlhood can find its precursor in a series of bestsellers from the 1960s, spearheaded by Helen Gurly Brown's Sex and the Single Girl (1962). The author later globalised the business of Cosmopolitan magazine, promoting a highly consumerist kind of western womanhood. The Single Girl, like Playboy at the time, propagated the notion of 'singleness' in which men and women were 'in a state of perpetual immaturity' and, therefore, they deconstructed the traditional notion of manhood and womanhood that were closely linked with family responsibility (Radner and Luckett, 1999: 10). However, such western materialist and consumerist girl cultures are in tension with the traditional family cultures that still play a relatively important role in East Asia. 


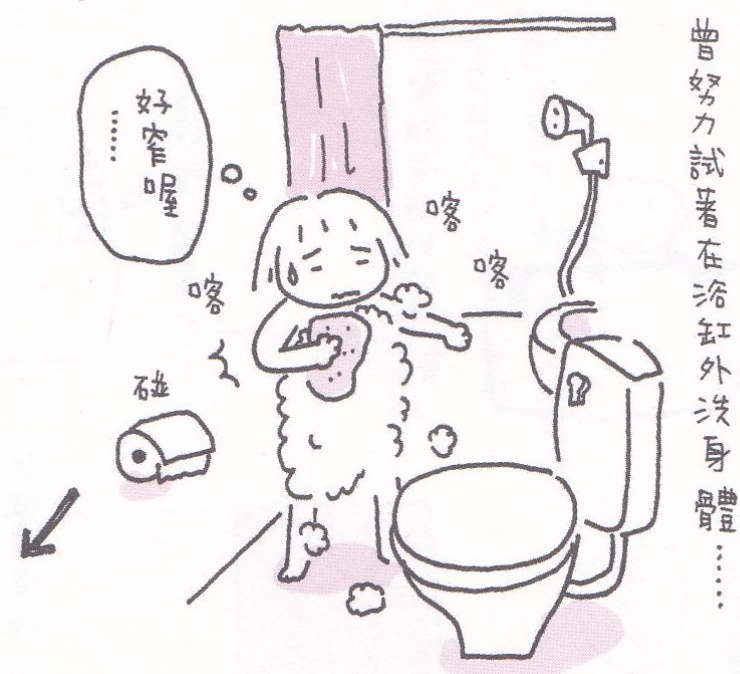

Figure 2. Takagi, N. (2005: 56). Hitorigurashi Mo 5 Nen Me. Courtesy of Naoko Takagi, Titan Publishing Co. Ltd. (Morning Star Group) (Taiwan) and Media Factory, Inc., affiliated to Kadokawa Future Publishing (Tokyo).

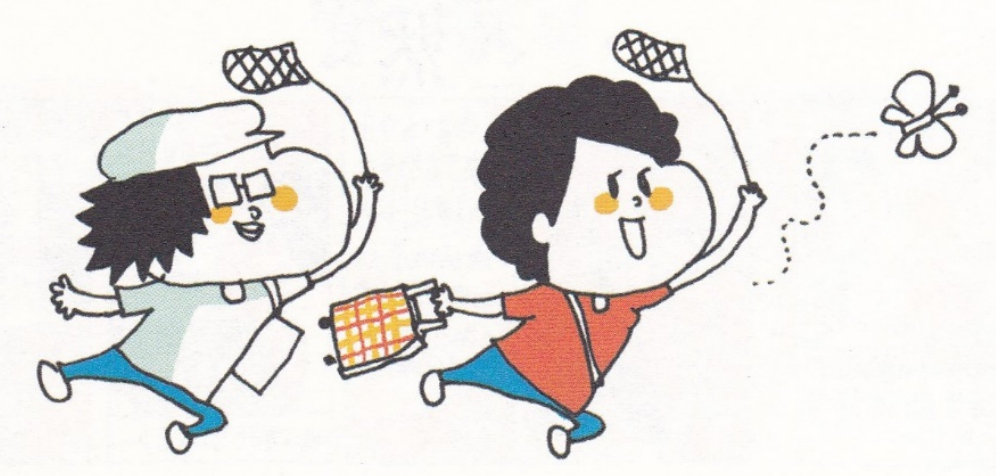

Figure 3. So, S. (2009: 92). The Base of an Old Girl. (Stella So (left) and her mother (right)). Courtesy of Stella So and Joint Publishing (Hong Kong).

\section{CUTENESS AND KAWAII}

The second and more prominent influence on the way in which Takagi and So picture themselves as small girls in their comic diaries concerns the 'kawaii' culture. The word kawaii is a derivation of kawai, which first appeared in Japanese classic literature in the eleventh century, referring to 'the sentiment of pity and empathy' and the 'persons and things that inspired such sentiment' (Köjien (1969: 477), quoted in Shiokawa, 1999: 95). By the nineteenth century, the word had gradually evolved into the adjective kawaii. According to the Japanese dictionary, Nibon Kokugo Daijiten, it means something or somebody who 1) 'looks miserable and raises sympathy'; 2) is 'attractive and adorable' (referring to young women and children); 3) 'small and beautiful'; and 4) 'innocent, and obedient' (like children). 'Kawaii' has also been added to the Oxford English Dictionary, where it is linked to the adjective 'cute' and the noun 'cuteness'. Therefore, 'kawaii and 'cute/cuteness' are only broadly similar but they actually carry different nuances (Nittono, 2016; Pellitteri, 2018).

Kawaii culture became more salient and even commodified after the Second World War in Japan, being partially influenced by the western culture of cuteness (Ngai, 2012:78; Shiokawa, 1999: 95). In the late nineteenth century, cute characters were seen in western comics. An example is in Palmer Cox's serialised comics The Brownies (18831918), whose characters have disproportionately large eyes and chubby faces. Citing Konrad Lorenz's (1971) ethnological explanation that babies' facial features can evoke humans' instinctive affections, Thierry Smolderen proposes that this big-eye 'genetic trait' was so widely adopted by artists that it gradually became a prominent feature of funny characters in the following century (Smolderen, 2014: 108). Tracing cuteness in the early twentieth century poetry studied by Hannah Arendt (1958), Sianne Ngai remarks on the linguistic 'cutification', which helps strengthen the association of cuteness with 'the infantile, feminine, and unthreatening' (Ngai, 2012: 3). 
The transnational impact of the big-eye trait in manga is obvious while the big eyes of many manga characters have gradually evolved into a variety of stylistically and aesthetically distinctive features. For example, enormous and sparkling eyes were a typical feature for girl characters in shöjo manga, but in the recent decades such a feature has also appeared in 'non-girl' and boy characters in the shönen'ai or the queer boy subgenre, propagating the fluidity and heterogeneity of gender (Tekeuchi, 2010: 87). Both cuteness and kawaii culture are associated with femininity and infantility, but kawaii culture has an additional connection with the specific 'girl-child subculture' in Japan (Shiokawa, 1999: 93).

On the one hand, So and Takagi's characters are inspired by shöjo manga in a generic sense, and intertwined with kawaii and cute aesthetics as well as the prevailing western cultural traditions of girlhood and kidulthood. On the other hand, their non-sexualised appearance and anecdotal narratives of solitude cannot be classified under mainstream shöjo manga, which generally revolve around the 'trinity of sex, love, marriage' (Fujimoto quoted in Takeuchi, 2010: 90). The images of Takagi and So's characters visualise the infantile connotation of kawaii and cuteness, similar to Ngai's observation of cute objects as 'simple or formally noncomplex' (Ngai, 2012: 59). In particular, Takagi's character with nondescript facial features, a bob hairstyle and a childlike body shape (Figure 2) resembles Momoko Sakura (Maruko) who is the nine-year-old main character in the highly popular manga and anime series Chibi Maruko-chan. Her drawing style is also characterised by simplistic strokes, which simulate a childlike drawing style. In comparison, So's visual imagery is less girlish and childlike because she mixes kawaï and zaniness in characterisation. For example, she draws herself with a chubby face with two patches of orange rather than pink cheeks. Pink cheeks are typically used to signify either a blush of shame or the rosy cheeks of children a marked feature of some kawaii children' characters, such as Maruko (Cohn and Ehly, 2016: 27). So probably uses orange rather than pink cheek colour to tune down the infantile and girly image of her character.

The cartooning style of So's character displays an infantile and overtly exaggerated body proportion with a large head and a disproportionately plump and blob-like body (Figures 3-4). This cartooning technique is similar to the chibi style, a manga technique used to temporarily turn a character into a highly deformed miniature version of itself to express an extreme emotion, because chibi literally means 'little/small person/child' (Cohn and Ehly, 2016: 22, 25). However, So uses this style as her standard look regardless of the emotional state of her character to produce a comical effect. Her facial expressions are also carefully rendered to establish her hilarious personality. For example, her mouth in profile is sometimes drawn in the shape of the Arabic number ' 3 ', which represents whistling, a mischievous and frivolous marker in manga (Cohn and Ehly, 2016: 22). When she is overjoyed, she laughs with a widely open crocodile-like mouth (Figure 7, panel 10 and 13). So sometimes depicts herself as asexual or even androgynous, by drawing stubble on her face (Figure 8). This flexible gender portrayal is in line with the way she pictures herself with a flat chest while her mother is consistently drawn with breasts, although these are not obvious in So's cartooning style (Figure 3). Thus, So's prepubescent figure suggests her intended rejection of a feminine body, which is shared by Takagi who also draws her silhouette similar to that of a small child in bathing scenes (Figure 2).

Emanata are comic icons conventionally used to represent motion, sound, various emotions and so on (Witek, 2012: 29; Walker, 2003). So often utilises them as humorous and kawaii markers. In Figure 4, So expresses how hot she felt during a summer night by drawing the curvy evaporating air and sweat drops (panel 10). Her cat Ding Ding came and wanted to talk to her, signified by an empty speech balloon, but by then So's face had become even more sweaty and she expressed her annoyance using two hot puffs of smoke popping out from her head (panel 11). Next, the narration says she kicked Ding Ding away by accident (as indicated by the motion lines from her foot and the spiky lines referring to a crash) so Ding Ding cried with two long tear streaks and yelled, 'How come you treat me like this?...You have changed! (panel 12 and my translation)' In panel 13, So narrates, 'In the middle of this stuffily hot night, the most terrible mosquito appeared. I could only apply 'White Flower Embrocation' (a strong-scented medicated embrocation to treat the mosquito bites and to serve as mosquito-repellent) all over my body (my translation)'. Her anger is channelled via her throbbing cruciform veins and there is an extradiegetic flying line and arrow labelling the flying route and location of the mosquito.

Different colours are applied to reflect changing moods across the panels. Across the four panels, the background colour changes from green, to orange, to red, which indicates a climax. After that, the background colour becomes green again as this colour signifies resolution. The colour of her face also changes from the default white to a lighter shade of orange and finally deep orange to display the escalation of anger or annoyance. 

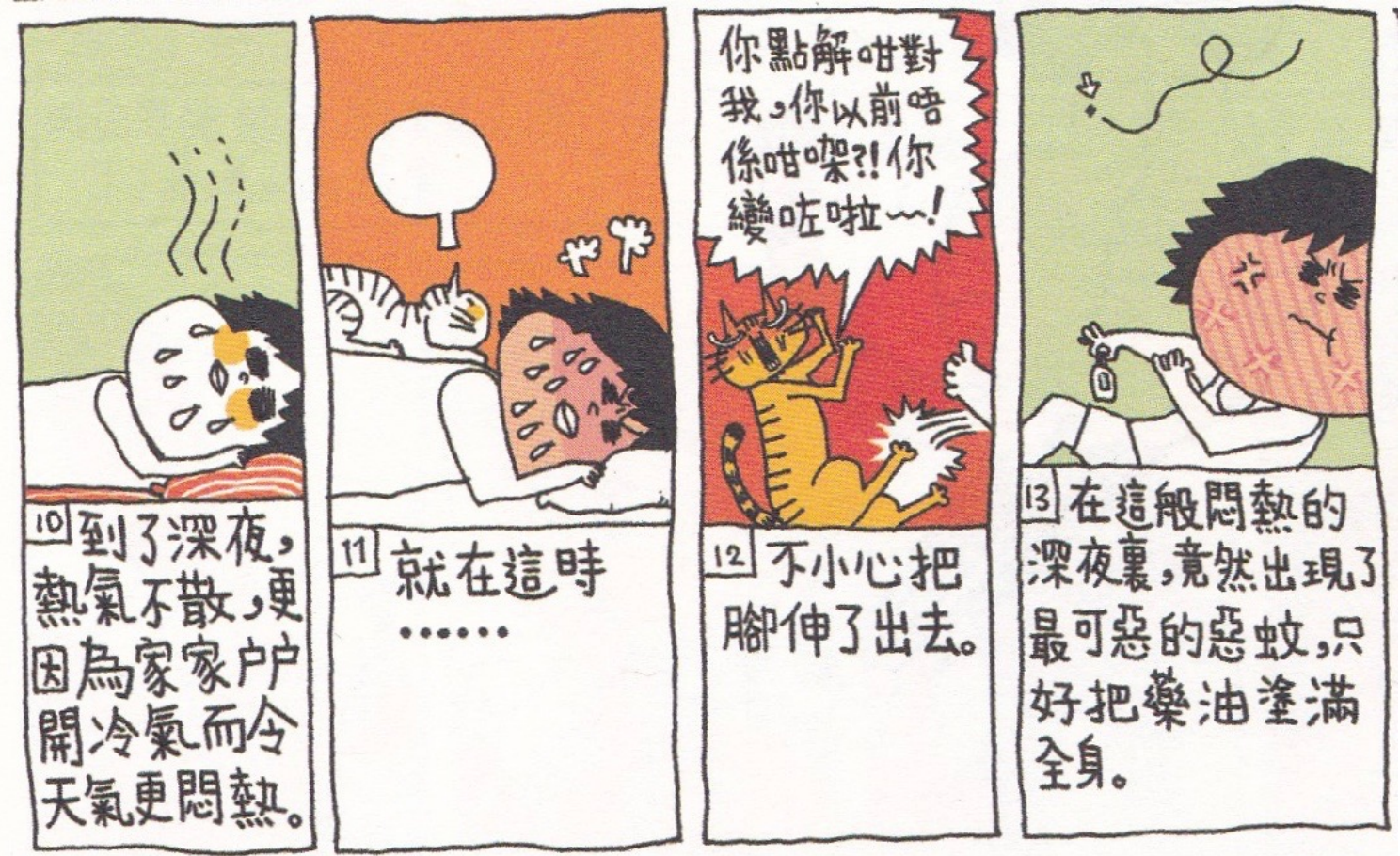

Figure 4. So, S. (2009: 131). The Base of an Old Girl, panel 10-13. Courtesy of Stella So and Joint Publishing (Hong Kong).

\section{THEMATIC ANALYSIS OF SINGLENESS}

Anglophone comix artists started to approach the topic of everyday life back in the 1960s (Cates, 2011; Schneider, 2010) but it only became the object of postmodern and feminist analyses in the 1980s (de Certeau, 1984; Lefebvre, 1984). Connecting this feminist trend with the development of shöjo manga, stories about the everyday lives of girls became more widespread in the late 1980s (Takeuchi 2010). While short comic strips about everyday life or current affairs started to become common in Hong Kong newspaper columns a few decades ago, it is not until the 2010s that the depiction of everyday life in comics started to raise growing public awareness (OUAT, 2019: 3).

The two comic diaries analysed include joyful anecdotes of living alone. Such narratives have foregrounded one issue, namely, girl-child-looking women embracing singleness through the discursive practices of solitary living. Combining the notion of singleness and solitary living, there is a body of social research studying singlehood and spinsterhood in modern societies. In earlier psychological and social research, an age-old marginalised and pathological social perception of singleness was presumed (Adams, 1976; Chasteen, 1994; Jeffreys, 1985). Nowadays, marginalised groups in general are gaining more social recognition. There has also been a more positive cultural shift in the representation of single women who deviate from the traditional homogeneous gender and social discourses (Sandfield and Percy, 2003). Several studies conducted in a British context have shown strong evidence that the concept of singleness varies across age, class and social environment (Macvarish, 2006; Simpson, 2005; Reynolds and Wetherell, 2003). Similar research results have been obtained in Hong Kong and Japan, both of which have a growing population of single women who are considered to be a 'somewhat anomalous category' in Japan (Rosenberger 2007: 94) and a 'normal deviance' in Hong Kong (Ng and Ng, 2009: 303) . $^{8}$

Eriko Maeda and Michael Hecht conducted a longitudinal study on the always-single Japanese women and found that they were marginalised (but not sanctioned) in Japan, a country that accentuates 'social conformity', but the women did seem to express a heightened self-acceptance over time (2012: 58). The positivity projected in Takagi's work also manifests this trend. Likewise, some Japanese TV dramas have been devoted to reflecting more diverse life options for women, with an aim to foster a more positive mentality within this group of single women and initiate a more constructive and open discussion in society at large. Two popular examples are Around 40 (2008) and Wonderful Single Life (2012) (the Japanese title Kekkon Sinai is literally translated as 'Do not get married'). Both

\footnotetext{
${ }^{8}$ In Japan, $22.7 \%$ of females aged 15 or above have never been married, according to a study conducted by the National Institute of Population and Social Security Research in 2015 (http://www.ipss.go.jp/p-info/e/psj2017/PSJ2017.asp). In Hong Kong, the never-married women population (aged 16 or above) is higher, accounting for $28 \%$ of the women population in 2016, according to the Census and Statistics Department of Hong Kong (https://www.censtatd.gov.hk/hkstat/sub/ sp160.jsp?productCode $=$ FA100055).
} 
TV dramas star the renowned actress Yuki Amami whose real life is similar to her on-screen roles. In an annual survey conducted by the Japanese media company Orion Inc (Orion News, 2012), Amami has been voted as 'the woman that Japanese women want to be the most' multiple times by Japanese women aged from 10 to 40 . This clearly indicates that people's attitudes to singleness are evolving in a more positive direction.

A similar research project studying the identity of single working women in Hong Kong found that participants actually faced 'little stigmatization' regarding their status as single women ( $\mathrm{Ng}$ and $\mathrm{Ng}, 2009$ : 303). However, this study provides little evidence on whether this is a temporal change of view or whether this view has been stable in Hong Kong culture for a longer period of time. Considering an old customary practice in the Pearl River Delta of China (mainly the Shunde region) where many women worked in the silk and textile industry and thus became financially independent, some of them became 'self-combed women' or celibate women who took a vow of lifelong celibacy and independence as 'a form of marriage resistance' (Branigan, 2014). Since the silk industry collapsed in the 1930s, many of them moved to Hong Kong and Southeast Asia to work as housemaids. In 1950, this centuriesold custom was banned in China after the implementation of the new marriage law. For decades, self-combed women were fairly visible and they have been culturally accepted in Hong Kong. So's satirical jokes about herself as an 'unmarried old girl' implies a certain degree of self-acceptance of her singleness.

Although the depiction of singlehood in Takagi and So's works is certainly an artistic or personal life choice, it also reflects a wider cultural shift in Hong Kong and Japan. What So and Takagi have in common are forms of social, cultural and economic capital which empower them to be well-educated and financially independent as professional graphic artists. They embody the concepts of 'female individualism' and 'new meritocracy' in modern and open societies where middle class women generally enjoy equal access to education, thus enabling them to make alternative life choices (McRobbie, 2004: 258). The western second-wave feminist point of view takes sexual liberty as one means of emancipation, but So and Takagi lead a solitary and celibate life, so it is difficult to judge if Takagi and So are sexually liberated or otherwise enslaved by the ingrained patriarchal social control of sexuality in their societies because their diaries do not include sexual partners. Instead, their diaries demonstrate selfactualisation, rather than sexual freedom, as a different causal link to emancipation.

When it comes to the notion of emancipation, Jan Bardsley, who studies women and marriage in modern Japan, observes that the term is seen in dichotomy with patriarchy in absolute terms without acknowledging the intertwining themes of control and resistance within the dominant patriarchal social structures (2004). As a result, there is a tendency to underestimate the feminist progress in Japan. In Hong Kong, Cheng (2009) suggests that there is a different interpretative framework towards the concepts of the female body and sexuality among the groups of Hong Kong women she studied, in which cultural taboos descended and derived from traditional Confucian propriety still carry weight for an individual woman's identity. Therefore, the less sexually provocative contents of So and Takagi's diaries compared with some well-studied western feminist comics, such as Julie Doucet's My New York Diary (1999) and Phoebe Gloeckner's The Diary of a Teenage Girl: An account in words and pictures (2002), have illustrated different values between individuals and society. This is not an essentialist claim for all western feminist comics versus East Asian comics. On the contrary, the diversity of feminist comics is never exhaustive. It is likely to cite some drastically different comics created by artists within the same culture.

This article delves into how So and Takagi construct their everyday life narratives using the aesthetics of cuteness and kawaii. Kawaii elements are clearly visible in Hitorigurashi due to the ubiquity of kawaii as a key constituent of modern Japanese culture (Kinsella, 1996; Masubuchi, 1994; Nittono, 2016; Yomota, 2006). Since the traditional role of women as homemakers is still highly valued in Japan, Takagi may have internalised such ideals and then prioritised managing her home over her work in her diary. This may explain why she divides her diaries into topical 'slice-of-life' stories without mentioning working at home as an artist. She only made one marginally work-related remark when complaining about her bulky computer and other home office appliances occupying too much space in her studio flat. Foregrounding her childlike acts but obscuring her profession in the story is widely acceptable because Japanese tend to 'view singles as more socially immature than their married counterparts regardless of their age', as suggested by Maeda and Hecht (2012: 50) who draw on the studies conducted by De Paulo and Morris (2005). In addition, this focus can also be partly explained by Yvonne Tasker and Dianne Negra's claim that career women may be perceived as less intimidating if they are portrayed as inexperienced girls (2005: 109); so these may be tactical strategies being deployed.

Since kawaii is also associated with innocent, obedient and unthreatening personalities, kawaii visual style can 'cutify' the practice of doing housework and further consolidate readers' association of a kawaii girl with doing housework. As a result, doing housework is mediated as a kawaii act which helps construct and support Takagi's femininity. Besides, she demonstrates an innocent trait by showing her teddy bear frequently in the story. For instance, in Figure 5, Takagi narrates her fear after watching a horror movie. Though she kept the light and TV on when she slept, she was still terrified by a slight movement of the balcony curtain. The personified teddy bear next to her 'felt' equally shocked, as indicated by the spiked upfixes emanata over both of their heads, and in this way the character is associated with childish vulnerability. 


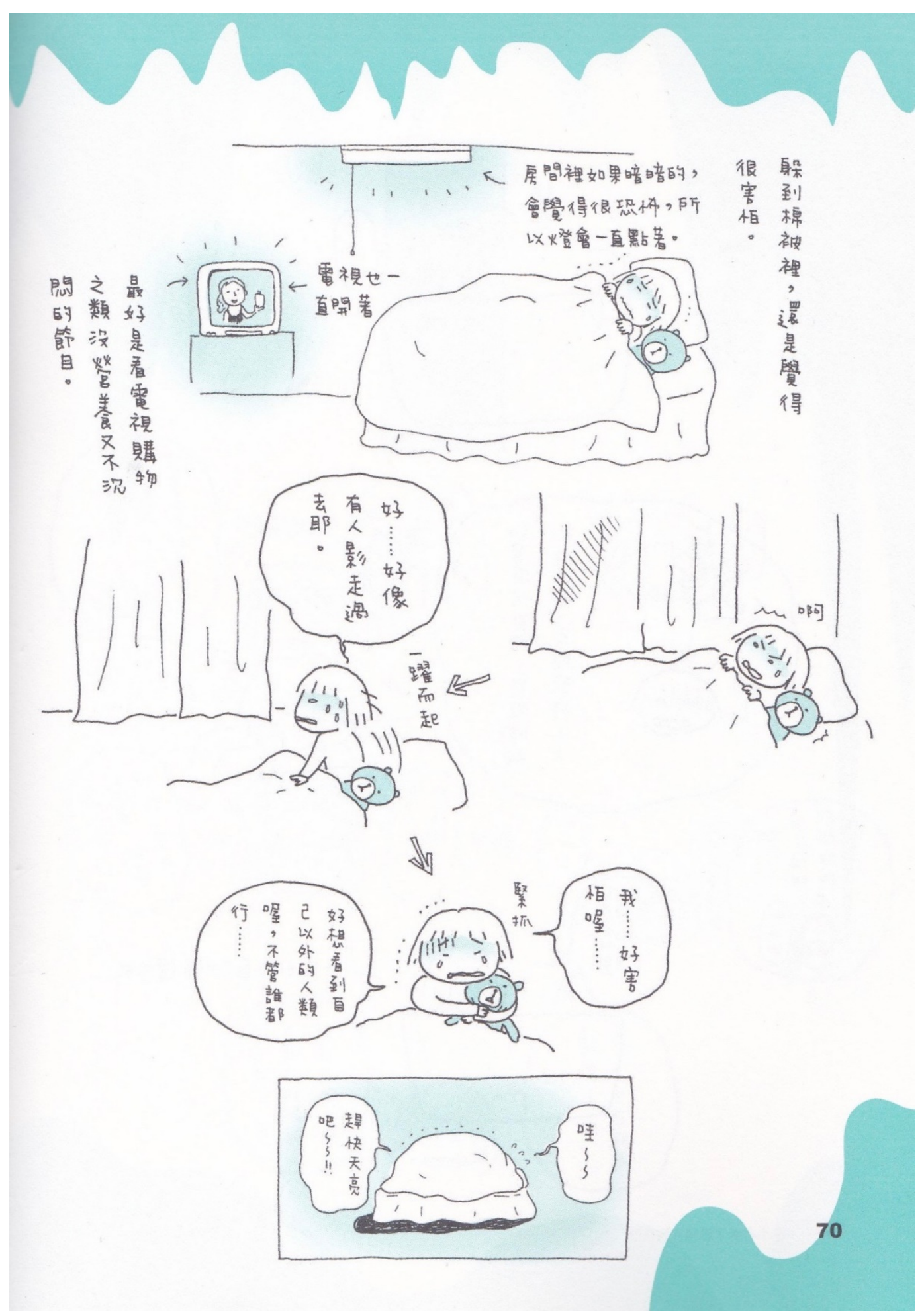

Figure 5. Takagi, N. (2005: 70). Hitorigurashi Mo 5 Nen Me. Courtesy of Naoko Takagi, Titan Publishing Co. Ltd. (Morning Star Group) (Taiwan) and Media Factory, Inc., affiliated to Kadokawa Future Publishing (Tokyo).

Figure 6 shows another scenario of kawaii characterisation by depicting Takagi's vulnerability. When her doorbell rings, Takagi checks who is ringing the doorbell by secretly crawling towards the peep hole of the door like a toddler in order to avoid casting her moving shadow on the window curtain beside the door, where the stranger is standing outside and might have seen her. However, before she reaches the door, the stranger has found out she is inside because he is peeking through the letterbox on her door. He then asks her to open the door, seemingly with ill intent, as he speaks in an eerie tone, lengthening the articulation of the word 'miss', which is indicated by two tildes. This frightens her so much that she hides herself under a blanket until the stranger leaves. Her reconstruction of this experience stresses her timidity in a way that may easily evoke readers' empathy and even protectiveness, which is a key emotion triggered by kawaii. 


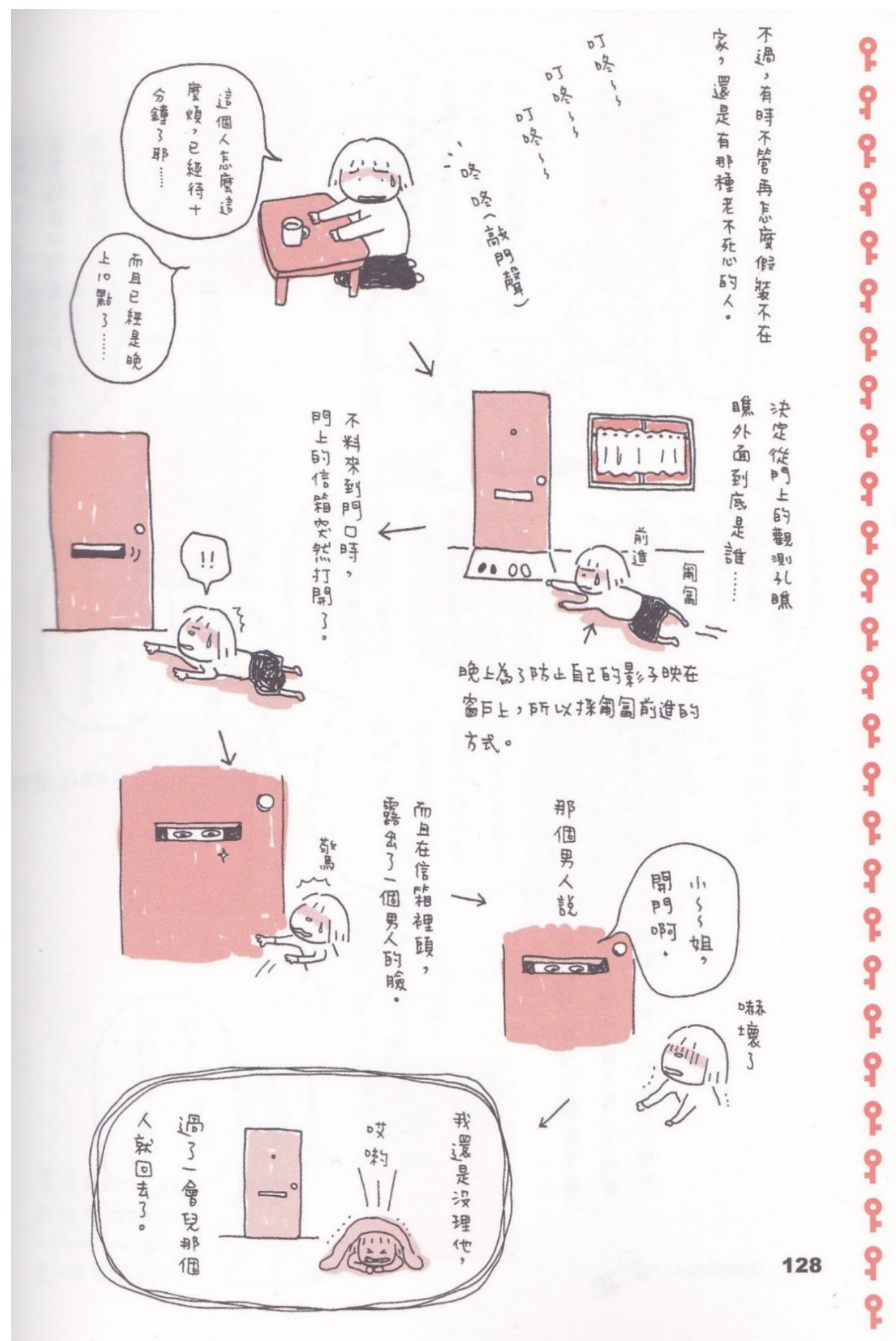

Figure 6. Takagi, N. (2005: 128). Hitorigurashi Mo 5 Nen Me. Courtesy of Naoko Takagi, Titan Publishing Co. Ltd. (Morning Star Group) (Taiwan) and Media Factory, Inc., affiliated to Kadokawa Future Publishing (Tokyo).

So has a different take on the representation of kawaii. Apart from infantilising her looks and behaviour, she incorporates self-deprecating humour and constantly mentions her profession. As a result, by contrast she depicts herself as a naughty kidult instead of a submissive little girl. In the preface, she states that The Base is her endeavour to prove that 'my dry life being single can be very juicy (So, 2009: 5, my translation)'. In this case, the English word 'dry' is used in the original Chinese text, where it is borrowed as a slang word with an additional cultural assumption that people who are not in a relationship must lead a dull life. 


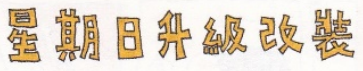
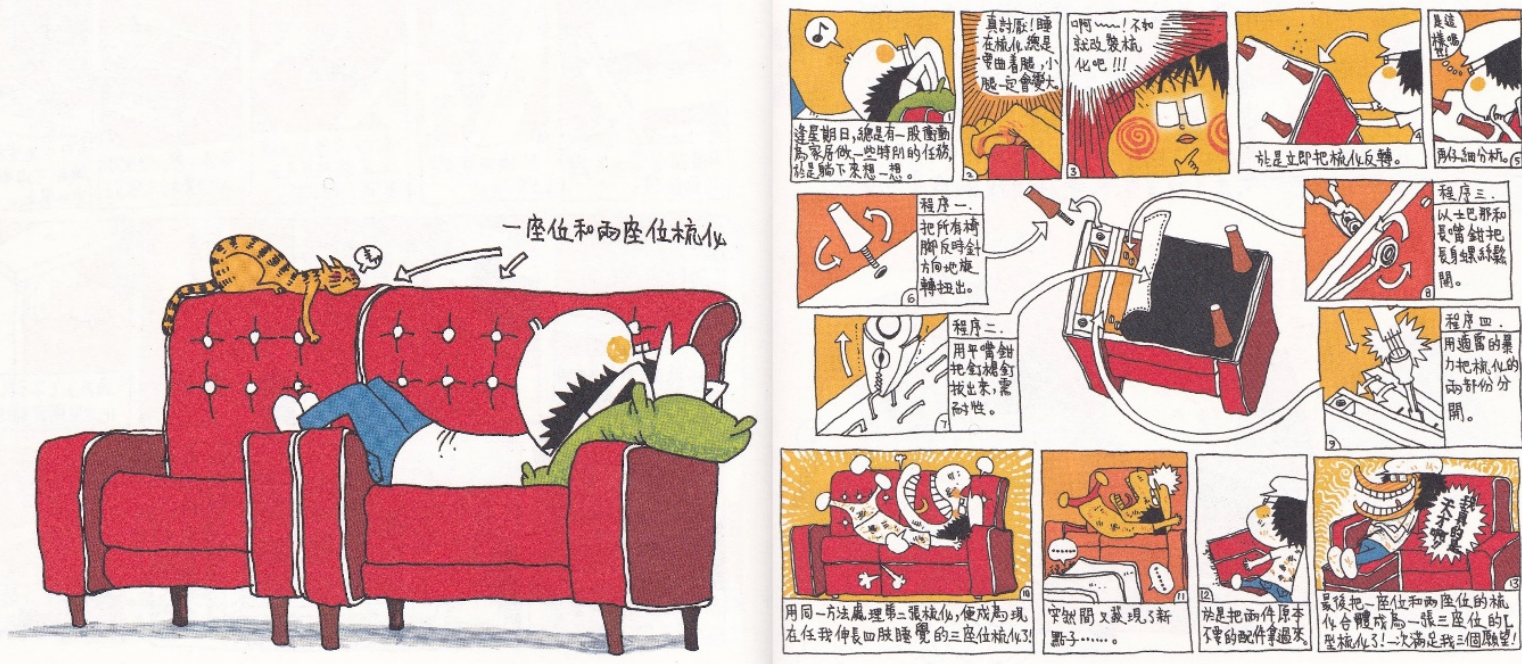

Figure 7. So, S. (2009: 30-31). The Base of an Old Girl. Courtesy of Stella So and Joint Publishing (Hong Kong).

So challenges the conventional notion of femininity in two ways: by projecting a cute/kawaii but sometimes androgynous or asexual imagery; and by intertwining childlike and professional behaviours. For example, in Figure 7 she demonstrates her carpentry skills, a traditional masculine domain. This verso, entitled 'Sunday Furniture Upgrade' (my translation), shows So and her cat lying on two sofas side by side. The recto illustrates how she transformed the two sofas into one big sofa and felt overjoyed by yelling 'I am really a genius! (my translation)' after accomplishing this task.

Allied with this, she sometimes parodies men's stubble. In Figure 8, she has stubble on her face after working for long hours but in the same story she also wears a skincare face mask, which is a more typical feminine practice (though this rigid gendered act is also changing with the new Asian masculinities). The text says, Nowadays old teenage girls are not only worried about no one wanting to marry them, but also about not getting their work done well. Therefore, all 'old girl warriors' seek different ways to keep their youthful looks' (my translation)'. Her satirical comment on the pressure faced by single and working women being caught between traditional (family) and contemporary (work) expectation is bitter, nevertheless she consistently delivers this message with light-hearted humour.

So and Takagi represent a strand of femininity that is in between the Single Girl and the kidult. They embrace economic independence but this strength is tempered by childlike imagery. In the Single Girl, sexuality is embodied through the 'technology of the body' because the female character tries to reach the beauty standard promoted by mass media through tools and technology, such as make-up and dietary pills. As a result, the Single Girl is influenced by consumerism and 'the codes of femininity as defined by heterosexuality' (Radner and Luckett, 1999: 15).

Without blindly following Single Gir/s beauty regime, So and Tagaki share many similarities with the kidult, whose perpetual immaturity is a form of resistance to the rigid social indicators of adulthood that are linked with family and work obligations. However, Takagi and So are also different from the kidult in their preference for stability achieved through professional success, and the financial sustainability that supports their positive selfidentity and solitary life. So states that she purchased her 'base' as her permanent home in case she would stay single for the rest of her life. However, So and Takagi are not regarded as militant feminists who refuse to enter romantic relationships. On the contrary, they seem to aspire to find a partner because they sometimes joke about being 'leftover girls' and share their fantasies about attractive men. Naoko Takagi seems to follow a traditional heterosexual trajectory as she has published a new comic book Otagai 40-Dai Kon (2018) (literally translated as 'getting married in my 40s') about dating, getting married and giving birth to her daughter. Similar to all her other works, this book contains no titillating scene or sensational descriptions about her romantic relationship. 


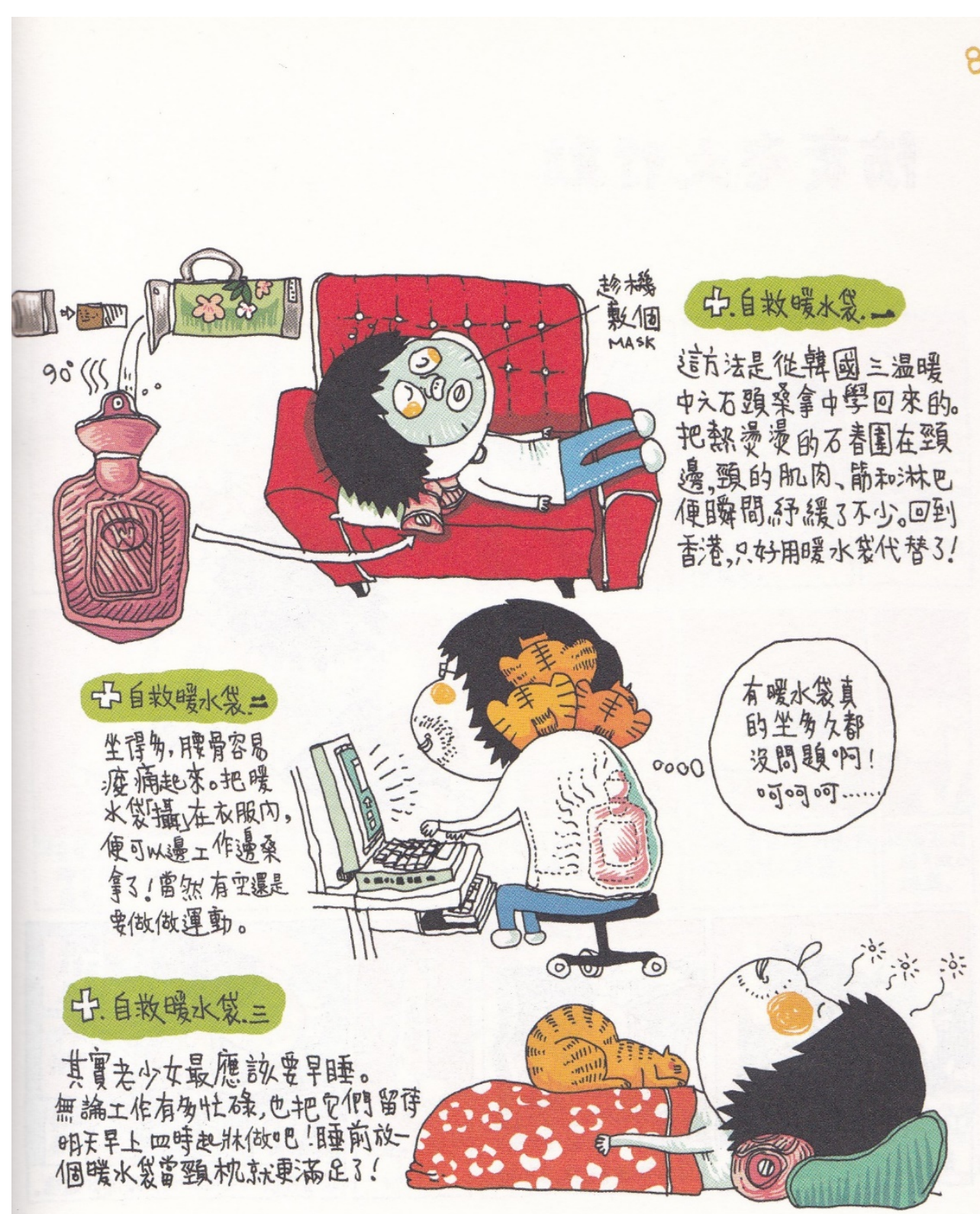

Figure 8. So, S. (2009: 83). The Base of an Old Girl. Courtesy of Stella So and Joint Publishing (Hong Kong).

The kawaii depictions of Takagi and So lighten the pejorative connotations of singlehood by demonstrating that the pursuit of happiness lies within themselves. This resonates with some of the canonical early feminist writings and speeches such as 'The Solitude of Self, delivered by Elizabeth Cady Stanton at the National American Woman Suffrage Association convention in 1892. It is one of the first feminist speeches that emphasises women's intellectual and spiritual independence and self-sovereignty. Similar ideas were shared by the pioneer Japanese feminist Raicho Hiratsuka who co-founded the first feminist magazine Seitō in 1911. In the debut issue, she referred to the deity Amaterasu who symbolises the sun in Shinto religion and ancient Japanese mythology. Hiratsuka commented that woman was seen as a real person and as the sun, but in a more recent history, that metaphor changed and she became the moon, a retrograde step in which woman then lost their glory, as the moon can only reflect light from the sun rather than being a light source in its own right (Hiratsuka, 2006: 160).

\section{CONCLUSION}

A feminist reading of Naoko Takagi's Hitorigurashi Mo 5 Nen Me and Stella So's The Base of an Old Girl reveals that their childlike female imagery and discursive practices are tied up with a wider feminist trend of girlhood and the aesthetics of cuteness and kawaii. These two trends have also been influenced by the postmodern phenomenon of kidult, which involves the infantilisation of adulthood, an in-between state of development.

These works have foregrounded some configurations of femininity that deviate from the conventional emphasis on the female body and sexuality in feminist studies. From a transcultural point of view, the comic 
characters of Takagi and So transgress the already blurred boundaries between girl and woman, and extend femininity to a pre-puberty stage. Their infantile girlhood can be read as influenced by the non-gender-specific kidult phenomenon that promotes perpetual immaturity. However, they have also complicated the paradigm of kidults by accepting some stable social thresholds of adulthood because they enjoy stability and independence in solitary living. All in all, they project an alternative kind of femininity that is not essentially connected to sexuality.

\section{ACKNOWLEDGEMENTS}

Sincerest thanks to Stella So, Naoko Takagi, Joint Publishing (Hong Kong), Titan Publishing Co. Ltd. (Morning Star Group) (Taiwan), and Media Factory Inc. (a company of Kadokawa Future Publishing) (Tokyo) for generously granting me the permission to use the comic images from The Base of an Old Girl and Hitorigurashi mo 5 nen me. My heartfelt thanks go to my supervisor Jan Baetens, the editors of this journal Sally M Munt and Nicole Streeten, and the two anonymous reviewers who read and gave me advice on my drafts. Special thanks to the Research Foundation of Flanders (FWO) for funding my research. Many thanks as well to Tomomi Yoshinaga for translating the Japanese correspondence between Kadokawa Future Publishing representatives and me.

\section{REFERENCES}

Adams, M. (1976) Single Blessedness: Observations on the single status in married society. New York: Basic Books.

Aldama, F. (2010). (ed.). Multicultural Comics: From Zap to Blue Beetle. Austin, Texas: Texas University Press.

Arendt, H. (1958). The Human Condition. Chicago: Chicago University Press.

Baetens, J., Frey, H. and Tabachnick, S. E. (eds.) (2018). The Cambridge History of the Graphic Novel. Cambridge: Cambridge University Press.

Bardsley, J. (2004). Women, marriage, and the State in modern Japan: Introduction. Womens Studies, 33(4), 353-359.

Berger, J. (1972). Ways of Seeing. London: Penguin.

Bernardini, J. (2014). The infantilization of the postmodern adult and the figure of kidult. Postmodern Openings, 5(2), 39-55.

Betterton, R. (1987). Looking On: Images of femininity in the visual arts and media. London: Pandora Press.

Bloom, L. E. (2010). Negotiating feminisms in Asian women's art. In Jones, A. (ed.), The Feminism and Visual Culture Reader (2n ed.) (pp. 14-18). London: Routledge.

Branigan, T. (2014). No regrets, say the Chinese women who chose independence over marriage, The Guardian, 3 July. Available at: https://www.theguardian.com/world/2014/jul/03/survivors-ancient-chinese-custom-selfcombed-women (Accessed 8 August 2019).

Bridges, B. (2003). Hong Kong and Japan: Commerce, culture and contention. The China Quarterly, 176, 1052-1067.

Brienza, C. (2015). (ed.). Global Manga: Japanese' comics without Japan? London: Routledge.

Brown, H. G. (1962). Sex and the Single Girl. New York: Bernard Geis Associates.

Cates, I. (2011). The diary comic. In Chaney, M. A. (ed.), Graphic Subjects: Critical essays on autobiograpby and graphic novels (pp. 209-226). Madison, Wisconsin: Wisconsin University Press.

Chan, S. (2009). Politics of female subjectivities and the everyday: The case of the Hong Kong feminist journal Niuliu. Feminist Review, 92, 36-53.

Chasteen, A. L. (1994). The world around me: The environment and single women. Sex Roles, 31(5/6), 309-328.

Cheng, S. (2009). Questioning global vaginahood: reflections from adapting the Vagina Monologues in Hong Kong. Feminist Review, 92, 9-35.

Chiang, L.H. and Liu, Y. (2011). Feminist geography in Taiwan and Hong Kong. Gender, Place \& Culture, 18(4), 557-569. https://doi.org/0.1080/0966369X.2011.583341

Chute, H. (2010). Graphic Women: Life narratives and contemporary comics. New York: Columbia University Press.

Cohn, N. and Ehly. S. (2016). The vocabulary of manga: Visual morphology in dialects of Japanese visual language. Journal of Pragmatics, 92, 17-29.

Darling-Wolf, F. (2015). Imagining the Global: Transnational media and popular culture beyond East and West. Anne Arbor, Michigan: Michigan University Press.

de Certeau, M. (1984). The Practice of Everyday Life. Rendall, S., (trans.). Berkley, California: UCLA Press.

DePaulo, B. M., and Morris, W. L. (2005). Singles in society and in science. Psychological Inquiry, 16, 57-83. https://doi.org/10.1207=s15327965pli162\&3_01

Denson, S., Meyer, C. and Stein, D. (2013). (eds.). Transnational Perspectives on Graphic Narratives: Comics at the crossroads. London: Bloomsbury Academics.

Gateward, F. and Pomerance, M. (eds.). (2002). Sugar, Spice, and Everything Nice: Cinema of girlhood. Detroit: Wayne State University Press. 
Gibson, M. (2015). Who does she think she is? Female comic-book characters, second-wave feminism, and feminist film theory. In M. Gibson, D. Huxley, and J. Ormrod (eds.), Superheroes and Identities (pp. 1-16 and pp. 135-146). London: Routledge.

Handyside, F, and Taylor-Jones, K. (2016). (eds.). International cinema and the girl: Local Issues, Transnational Contexts. London: Palgrave Macmillan.

Harris, A. (2004). All About the Girl: Culture, power and identity. London: Routledge.

Hatfield, C. (2005). Alternative Comics: An emerging literature. Jackson, Mississippi: Mississippi University Press.

Heimermann, M. and Tullis, B. (ed.). (2017). Picturing Childhood: Youth in transnational comics. Austin, Texas: Texas University Press.

Hiratsuka, R. (2006). In the Beginning, Woman was the Sun: An Autobiography of a Japanese Feminist- Hiratsuka Raichö. Translated with an introduction and notes by Teruku Craig. Columbia University Press.

Hirschmann, N. (2003). The Subject of Liberty: Toward a feminist theory of freedom. New Jersey: Princeton UP.

Ito, K. (2005). A history of manga in the context of Japanese culture and society. Journal of Popular Culture, 38(3), 456-475.

Jeffreys, S. (1985) The Spinster and her Enemies: Feminism and sexuality 1880-1930. London: Pandora Press.

Johnson, M. (2016). Today's feminist comics: Why I don't relate. The Comics Journal. March 6. Available at http:/ /www.tcj.com/todays-feminist-comics-why-i-dont-relate/ (Accessed 8 March 2019).

Jones, A. (2010). (ed.). The Feminism and Visual Culture Reader (2nd ed.). London: Routledge.

Oricon News (2012). Josei ga erabu ‘ī on’na’ rankingu, amami yuki ga 4 renpa (女性が選ぶ’イイ女’ランキン グ、天 海 祐 希 が 4 連 覇 ). Oricon News, 27 May 2012, Available at https://www.oricon.co.jp/news/2011032/full/\#rk. (Accessed 7 March 2020).

Kinsella, S. (1996). Cuties in Japan. In Skov, L. and Moeran, B. (eds.), Women, Media and Consumption in Japan (pp. 235-53). Honolulu, Hawaii: Hawaii University Press.

Kirtley, S. (2018). 'A word to you feminist women': The parallel legacies of feminism and underground comics. In Baetens, J., Frey, H. and Tabachnick, S. E. (eds.), The Cambridge History of the Graphic Novel (pp. 269-285). Cambridge: Cambridge University Press.

Klein, S. (1993). Breaking the mold with humor: Images of women in the visual media. Art Education, 46(5), 60-5. Köjien. (ed.). (1969). Shinmura Izuru (2 $2^{\text {nd }}$ ed.). Tokyo: Iwanami Shoten.

Lai, C. S. and Wong, D. H. (2003). Japanese comics coming to Hong Kong. In Befu, H. and Guichard-Anguis, S. (eds.) Globalizing Japan: Ethnography of the Japanese presence in Asia, Europe, and America (pp. 111-120). London: Routledge,

Lefebvre, M. (1984). Everyday Life in the Modern World. Rabinovitch, S. (trans.). New Jersey: Transaction Publishers.

Lent, J. (2015). Asian Comics. Jackson, Mississippi: Mississippi University Press.

Lorenz, K. (1971). Part and parcel in animal and human societies. Studies in Animal and Human Behaviour, 2, 115195.

Macvarish, J. (2006). What is 'the problem' of singleness? Sociological Research Online, 11(3), 1-8. https://doi.org/10.5153/sro.1418

Maeda, E. and Hecht, M. L. (2012). Identity search: interpersonal relationships and relational identities of alwayssingle Japanese women over time. Western Journal of Communication, 76(1), 44-64. https://doi.org/10.1080/10570314.2012.637539

Masubuchi, S. (1994). Kawaii Shokogun/Kawaii Syndrome. Tokyo: Nihon Hoso Shuppan Kyokai.

McRobbie, A. (2004). Post-feminism and popular culture. Feminist Media Studies, 4(3), 255-264.

Ng, E. G. H and Ng, C. W. (2009). Single working women in Hong Kong: A case of 'normal deviance'. In K. Chan and A. Ku (eds.), Doing Families in Hong Kong (pp. 303-335). Leiden, Netherlands: Brill.

Ngai, S. (2012). Our Aesthetic Categories: Zany, cute, interesting. Cambridge, Massachusetts: Harvard University Press.

Nittono, H. (2016). The two-layer model of 'kawaii': A behavioural science framework for understanding kawaii and cuteness. East Asian Journal of Popular Culture, 2(1), 79-95. https://doi.org/10.1386/eapc.2.1.79_1

Once Upon A Time: OUAT, Hong Kong Comics Touring Exbibition. (2019). Hong Kong: Hong Kong Arts Centre, 2019. Available at: https://www.hkac.org.hk/calendar_detail/?u=Tt5Di_Cjbt0\&lang=en (Accessed 8 January 2019).

Pelitteri, M. (2018). Kawaii aesthetics from Japan to Europe: Theory of the Japanese 'cute' and transcultural adoption of its styles in Italian and French Comics production and commodified culture goods. Arts, 7(3), 24, https://doi.org/10.3390/arts7030024

Radner, H. and Luckett, M. (eds.). (1999). Swinging Single: Representing sexuality in the 1960s. Minneapolis, Minnesota: Minnesota University Press.

Reynolds, J. and Wetherell, M. (2003). The discursive climate of singleness: Consequences for women's negotiation of a single identity. Feminism \& Psychology, 13(14), 489-510.

Robbins, T. (1999). From Girls to Grrlz: A bistory of women's comics from teens to zines. San Francisco: Chronicle Books. 
Roger B. (1989). From reoccupation to EXPO: Hong Kong-Japanese relations, 1945-70. Shakai Kaboku Jaanaru, $28,50-52$.

Rosenberger, N. (2007). Rethinking emerging adulthood in Japan: perspectives from long-term single women. Child Development Perspectives, 1(2), 92-95.

Sabin, R. (1996). Comics, Comix and Grapbic Novels. London: Phaidon.

Sandfield, A. and Percy, C. (2003). Accounting for single status: Heterosexism and ageism in heterosexual women's talk about marriage. Feminism \& Psychology, 13(4), 475-488.

Schneider, G. (2010). Comics and everyday life: From ennui to contemplation. European Comic Art, 3(1), 37-63.

Schodt, F. L. and Tezuka, O. (1986). Manga! Manga! The World of Japanese comics. Tokyo: Kodansha International.

Shiokawa, K. (1999). Cute but deadly: Women and violence in Japanese comics. In Lent, J. A. (ed.), Themes and Issues in Asian Cartooning (pp. 93-126). Madison, Wisconsin: Wisconsin University Press.

Simpson, R. E. H. (2005). Contemporary Spinsterhood in Britain: Gender, partnership status and social change (PhD thesis). The London School of Economics and Political Science (LSE).

Smolderen, T. (2014). The Origins of Comics: From William Hogarth to Winsor McCay, translated by Bart Beaty and Nick Nguyen (trans.). Jackson, Mississippi: Mississippi University Press.

So, S. (2009). 老少女基地 (The Base of an Old Girl). Hong Kong: Jointing Publishing.

Stanton, E. C. (1915). The Solitude of Self. Library of Congress. Available at: https://www.loc.gov/resource/rbnawsa.n8358/?sp=2 (Accessed 4 April 2019).

Streeten, N. and Tate, C. (2017). (eds.). The Inking Woman: 250 years of women cartoon and comic artists in Britain. Brighton and Hove: Myriad Editions.

Takagi, N. (2003). $150 \mathrm{~cm}$ ライフ. Tokyo: Media Factory Inc. Translated title: $150 \mathrm{~cm}$ Life, trans. Yu-jun Hung (trans.) Taipei: Titan Publish Co. Ltd.

Takagi, N. (2003). Hitorigurashi Mo 5 Nen Me (Original Japanese title: ひとりぐらしも 5 年め.

Tokyo: Media Factory Inc., 2003. Translated title: 一個人住第五年), Yu-jun Hung (trans.), Taipei: Titan Publishing Co. Ltd.

Tasker, Y. and Negra, D. (2005). InFocus: Postfeminism and contemporary media studies. Cinema Journal, 44(2), 107-110.

Takeuchi, K. (2010). The genealogy of shōjo manga (girls' comics) studies. U.S.- Japan Women's Journal, 38, 81-112.

Walker, M. (2003). The Lexicon of Comicana. Port Chester, NY: The Museum of Cartoon Art.

Walker, R. (2006). Becoming the Third Wave. In Heywood, L. (ed.), The Women's Movement Today: An encyclopaedia of third-wave feminism, vol. 2, (pp. 3-5). Westport, CT: Greenwood.

Witek, J. (2012). Comics modes: Caricature and illustration in the Crumb Family's Dirty Laundry. In M. J. Smith and R. Duncan (eds.), Critical Approaches to Comics: Theories and methods (pp. 27-42). London: Routledge.

Wong, W. S. Y. (2006). Globalizing manga: From Japan to Hong Kong and beyond. Mechademia, 1, 23-45.

Yomota, I. (2006). 'Kawaii' Ron/ Essay on 'Kawaii'. Tokyo: Chikuma ShobO.

Yoshihara, M. (2004). The flight of the Japanese Butterfly: Orientalism, nationalism and performances of Japanese womanhood. American Quarterly, 56(4), 975-1001.

Citation: Chu, K.-W. (2020). Women Living in Solitude: A Case Study of The Base of an Old Girl and Hitorigurashi Mo 5 Nen Me. Feminist Encounters: A Journal of Critical Studies in Culture and Politics, 4(1), 06. https://doi.org/10.20897/femenc/7910

Copyright (C) 2020 by Author/s and Licensed by Lectito BV, Netherlands. This is an open access article distributed under the Creative Commons Attribution License which permits unrestricted use, distribution, and reproduction in any medium, provided the original work is properly cited. 